Biochemical Journal: this is an Accepted Manuscript, not the final Version of Record. You are encouraged to use the Version of Record that, when published, will replace this version. The most up-to-date version is available at http://dx.doi.org/10.1042/BCJ20180384. Please cite using the DOI 10.1042/BCJ20180384

\title{
Repurposing of Idebenone as a potential anticancer agent
}

\author{
Elisabetta Damiani ${ }^{1,2}$, Raif Yuecel, ${ }^{3}$ Heather M. Wallace ${ }^{1 *}$
}

${ }^{1}$ Institute of Medical Science,

School of Medicine, Medical Sciences and Nutrition, University of Aberdeen,

Aberdeen, UK

${ }^{2}$ Current address: Department of Life and Environmental Sciences, Polytechnic University of the Marche, Ancona, Italy

${ }^{3}$ Iain Fraser Cytometry Centre, Institute of Medical Sciences, University of Aberdeen, Aberdeen, UK

*Corresponding author: Professor Heather M. Wallace. IMS Room 6.21, Foresterhill, Aberdeen AB25 2ZD; h.m.wallace@abdn.ac.uk; +44 1224437956

7 Running title: Anti-proliferative effects of idebenone 


\section{Abstract}

Glioblastoma (GB) represents the most common and aggressive form of malignant primary brain tumour associated with high rates of morbidity and mortality. In this study we considered the potential use of idebenone, a Coenzyme $\mathrm{Q}_{10}$ analogue, as a novel chemotherapeutic agent for GB. On two GB cell lines, U373MG and U87MG, idebenone decreased the viable cell number and enhanced the cytotoxic effects of two known anti-proliferative agents: temozolomide and oxaliplatin. Idebenone also affected the clonogenic and migratory capacity of both GB cell lines, at $25 \mu \mathrm{M}$ and $50 \mu \mathrm{M}$, a concentration equivalent to that transiently reached in plasma after oral intake that is deemed safe for humans. p21 protein expression was decreased in both cell lines indicating that idebenone likely exerts its effects through cell cycle dysregulation and this was confirmed in U373MG cells only by flow cytometric cell cycle analysis which showed S phase arrest. Caspase-3 protein expression was also significantly decreased in U373MG cells indicating idebenone-induced apoptosis that was confirmed by flow cytometric Annexin V/PI staining. No major decrease in caspase-3 expression was observed in U87MG cells nor apoptosis as observed by flow cytometry analysis. Overall, the present study demonstrates that idebenone has potential as an anti-proliferative agent for GB by interfering with several features of glioma pathogenesis such as proliferation and migration and hence might be a drug that could be repurposed for aiding cancer treatments. Furthermore, the synergistic combinations of idebenone with other agents aimed at different pathways involved in this type of cancer is promising.

Keywords: Idebenone; glioblastoma cells; anti-proliferation, anti-migration; p21

\section{Introduction}

Glioblastoma (GB) represents the most common and aggressive form of malignant primary brain tumour and is associated with high rates of morbidity and mortality (1). Despite the substantial advances in neurosurgical techniques in combination with radio/chemotherapy, the median overall survival time of GB patients remains only approximately 8-15 months and it has not changed significantly over the past four decades (2). This is reflected in the limited success of recent phase III clinical trials making treatment of GB one of the greatest challenges in neuro-oncology (3). In the attempt to improve treatment outcomes of GB patients and to increase their survival rate and quality of life, a diverse range of therapeutic strategies are being explored. These include immunotherapy, nanoparticles encapsulating anti-cancer agents, gene therapy along with the substantial need for exploring and developing new, effective and safe chemotherapeutic agents (4). An important prerequisite for the success of any drug for this disease is that of crossing the blood brain barrier (BBB) even though this barrier is disrupted at the brain-tumour interface (5). One such compound that has been shown to cross the BBB following oral administration using ${ }^{14} \mathrm{C}$ radiolabel in both rats and 
dogs is idebenone (IDE) $(6,7)$. IDE is exploited currently by the pharmaceutical industry to treat agerelated cognitive disorders including Alzheimer's disease due to its powerful antioxidant properties $(8,9)$, and it has recently been used with success for treatment of several mitochondrial relatedneuromuscular disorders, especially Leber's hereditary optic neuropathy and Friedrich's ataxia (1014). Chemically, IDE is structurally similar to the naturally occurring Coenzyme $Q_{10}$ (Fig. 1), in that both possess a benzoquinone moiety involved in electron transport, but their hydrophobic tails differ in length and composition. The shorter tail of IDE seems to be the ideal length for favouring partitioning into the mitochondrial membrane and for a better BBB permeation compared to Coenzyme $\mathrm{Q}_{10}(15)$. It therefore, has a more favourable pharmacokinetic profile and, in some cases, is considered a better therapeutic agent than its natural analogue $(16,17)$.

Recent research suggests that IDE may also have potential use as an anti-cancer agent. Tai et al. studied the effect of IDE on human dopaminergic neuroblastoma SHSY-5Y cells demonstrating that concentrations $\geq 25 \mu \mathrm{M}$ were cytotoxic and that the mechanism of cell death was apoptotic in nature (18). Seo et al. showed that in PC-3 prostate cancer cells and in CFPAC-1 pancreatic ductal adenocarcinoma cells, IDE reduced cell proliferation, inhibited cell migration and induced apoptosis by inhibiting anoctamin 1 (ANO1), a calcium activated chloride channel which is significantly increased in various tumours (19). These are the only two studies that have specifically investigated the effects of IDE on human cancer cells to date. Both demonstrated that it was effective, highlighting the potential this compound has as an anti-proliferative agent if studied more extensively on other cancer cell lines. For these reasons, IDE could be an interesting candidate for investigation against GB.

Therefore the aim of the study was to investigate the influence of IDE on growth, regulation and migration of two human GB cell lines, U87MG and U373MG, in order to determine whether IDE might be a potential new anticancer agent.

\section{Materials and Methods}

\section{Cell Culture and Reagents}

Idebenone (Tocris, UK) and Temozolomide (Sigma, USA) were both prepared as a $100 \mathrm{mM}$ stock solution in dimethyl sulphoxide (DMSO), whereas Oxaliplatin (Tocris, UK) was prepared as a $10 \mathrm{mM}$ stock solution in sterile water. They were all aliquoted and stored at $-20{ }^{\circ} \mathrm{C}$ until use. The following antibodies were purchased from different sources: anti-p21/WAF1/Cip74 (\#05-655, EMD Millipore, USA), anti-ß-Actin (\#Ab1 19716, Abcam, USA), anti-Casp3 (\#HPA002643, Sigma, USA), anti-rabbit and anti-mouse IgG-HRP (\#sc-2004, \#sc-2005 respectively, Santa Cruz Biotechnology, USA). All other analytical grade chemicals were purchased from Sigma-Aldrich (USA).

Human glioblastoma cell lines, U373MG and U87MG were procured from ECACC and are commonly used as models of glioblastoma harbouring a range of different genetic lesions (20). They 
were cultured in Eagle's minimum essential medium (MEM) supplemented with $10 \%$ fetal bovine serum (FBS), 100 units $/ \mathrm{mL}$ penicillin, $100 \mu \mathrm{g} / \mathrm{mL}$ streptomycin, $2 \mathrm{mM} \mathrm{L-glutamine,} \mathrm{under} \mathrm{standard}$ cell culture conditions $\left(37{ }^{\circ} \mathrm{C}, 5 \% \mathrm{CO}_{2}\right.$, humidified atmosphere), passaged every $4 / 5$ days and used within 8-20 passages. Prior to each experiment, they were seeded in appropriate plates/dishes at a seeding density of $2.4 \times 10^{4}$ cells $/ \mathrm{cm}^{2}$ and treated according to each assay protocol. Appropriate controls were included throughout including the use of maximum concentration of vehicle that the cells were exposed to which did not exceed $0.05 \%$ for DMSO. This concentration did not cause any observable harmful effects on the cells based on cell morphology and cell growth.

\section{MTT and Trypan Blue exclusion assays and cell growth analysis}

Cells were seeded onto 96-well plates and allowed to grow for $48 \mathrm{~h}$ after which medium was replaced with that containing increasing concentrations of the chosen drugs or their combinations (100 $\mu \mathrm{L}$ final volume). For combination studies, the drugs were added simultaneously. After different exposure times (24-72 h), the effects of the compounds on cell viability was determined using the 3(4,5-dimethylthiazol-2-yl)-2,5-diphenyltetrazolium bromide (MTT) assay (21). Ten $\mu \mathrm{L}$ of MTT solution in PBS $(5 \mathrm{mg} / \mathrm{mL})$ were added to each well and cells were incubated for a further $3 \mathrm{~h}$ at $37^{\circ} \mathrm{C}$. Medium was removed and replaced with $100 \mu \mathrm{L}$ of DMSO to solubilize the crystals. The optical density of each well was determined at $570 \mathrm{~nm}$ on a microplate reader (Tecan Sunrise ${ }^{\mathrm{TM}}$ ) and viable cell count was assessed as a percentage relative to untreated cells. The $\mathrm{IC}_{50}$ values for each drug were calculated using GraphPad Prism 7 XML Project (GraphPad Software Inc. San Diego, USA).

For cell growth analysis, cells were seeded in $35 \mathrm{~mm}$ cell culture dishes in $2 \mathrm{~mL}$ medium in duplicate and allowed to grow for $48 \mathrm{~h}$, after which medium was replaced with that containing different concentrations of IDE and incubated for a further $48 \mathrm{~h}$. Cells were then harvested by trypsinization, resuspended in $1 \mathrm{~mL}$ PBS and counted on an automated cell counter (Beckman Z2 Coulter Particle Count and Size Analyzer). For determining the number of dead/dying cells, the trypan blue exclusion dye assay was used. The same procedure as described above for cell growth analysis was followed, except that cells were counted under light microscopy on a hematocytometer after staining with $0.1 \%$ trypan blue solution in PBS at a 10x dilution factor. The number of dead/dying cells (stained) was assessed as a percentage of the total cell number for each treatment.

\section{Colony formation assay}

The colony forming assay was performed to evaluate the effects of IDE on the clonogenic capacity of U373MG and U87MG cells. Cells were seeded in $60 \mathrm{~mm}$ cell culture dishes in duplicate (200 and 400 cells respectively/2.5 mL medium) and after $4 \mathrm{~h}$ (to allow cells to attach), $2.5 \mathrm{~mL}$ of appropriate concentrations of IDE were added in order to reach the desired final concentrations in $5 \mathrm{~mL}$. Cells were then left in a sealed incubator for 2 weeks, after which they were carefully rinsed with PBS, 
fixed and stained with $2 \mathrm{~mL} 0.5 \%$ crystal violet solution in 50\% methanol for $30 \mathrm{~min}$, rinsed again carefully with tap water and left to dry in normal air at room temperature. Colonies containing more than 50 cells were counted as representative of clonogenic cells under a Carl Zeiss ${ }^{\mathrm{TM}}$ Stemi 2000-C stereo microscope. The surviving fraction which is the number of colonies that arise after cell treatment expressed in terms of plating efficiency, was determined according to the formula reported in Franken et al. (22): ((no. of colonies formed after treatment)/(no. of cells seeded x plating efficiency of the control)).

\section{Cell migration assay}

The effect of IDE on cell migration was assessed using the scratch/wound assay as previously developed by Valster et al. (23). The cells were grown to confluence in a 6-well cell culture plate for $72 \mathrm{~h}$, washed twice with medium without FBS and a scratch was performed with the tip of a sterile $200 \mu \mathrm{L}$ pipette tip to create a defined, uniform scratch in the centre of the well. Medium with suspended cells was removed and replaced with medium containing 0.5\% FBS with or without different concentrations of IDE. Closure of the wounds by migrating cells was observed under a digital inverted microscope (Evos XL, AMG), right after the scratch and at 24 and $48 \mathrm{~h}$ of incubation and images were taken in the same field by marking the wells underneath. An average of six images/well/time point were taken and the gap surface area of the wound was analysed using Image $\mathbf{J}$ software and expressed as the percentage of the area at time $0 \mathrm{~h}$.

\section{Western immunoblotting analysis}

Cells were seeded onto $60 \mathrm{~mm}$ diam. dishes in duplicate, and after $48 \mathrm{~h}$, the medium was replaced with different concentrations of IDE and incubated for a further $48 \mathrm{~h}$. Cells were then harvested and the lysates in RIPA buffer were stored at $-80{ }^{\circ} \mathrm{C}$. After thawing, brief vortexing and centrifugation at $16000 \mathrm{~g}$ for $15 \mathrm{~min}$ at $4{ }^{\circ} \mathrm{C}$, the protein concentration was determined on the supernatant using the BCA protein assay according to the manufacturer's instructions (Pierce BCA Protein assay kit, Thermo Scientific, USA). Samples containing equal amounts of protein were separated by $12 \%$ SDSPAGE and the proteins were transferred overnight at $4{ }^{\circ} \mathrm{C}$ on PVDF membranes and probed for the proteins of interest as previously reported (24). The primary antibodies were used at the following dilutions: anti-p21 (1:750), anti-pro-caspase3 (1:500), anti- $\beta$-actin (1:5000), while the secondary ones were 1:7000 for anti-rabbit and 1:3000 for anti-mouse HRP-labelled antibodies. The protein bands were detected using an enhanced chemiluminescent substrate (Supersignal West Dura, Thermo Scientific, USA) and captured on a Genoplex VWR Bio imager (VWR, USA). Protein bands were quantified using Image $\mathbf{J}$ software and the data are reported as the percentage of intensity of the band of the protein of interest compared to the intensity of the $\beta$-actin band (control). 


\section{Flow cytometry analyses}

Cells were seeded onto 6-well plates and allowed to grow for $48 \mathrm{~h}$ after which medium was replaced with that containing different concentrations of IDE or camptothecin $(1 \mu \mathrm{M})$ used as positive control, and incubated for $24 \mathrm{~h}$. Cells were then harvested by trypsinization and combined with floating cells collected from the medium, pelleted, and washed with PBS. For Annexin V/propidium iodide (PI) staining, the Annexin V-FITC Kit (Miltenyi Biotec, Germany) was used and the assay was performed according to the manufacturer's protocol. Briefly, after washing cells with $1 \mathrm{x}$ annexinbinding buffer, cells were resuspended in $100 \mu \mathrm{L} 1 \mathrm{x}$ annexin-binding buffer to which $10 \mu \mathrm{L}$ of Annexin V-FITC was added and incubated for $15 \mathrm{~min}$ at room temperature. Cells were then washed with $1 \mathrm{~mL} 1 \mathrm{x}$ binding buffer, and to the cell pellet resuspended in $500 \mu \mathrm{L}$ of this same buffer, $5 \mu \mathrm{L}$ of PI solution was added directly before measurement on a BD Fortessa flow cytometer (BD Bioscience, USA). Emission of Annexin V-FITC was detected at $530 \mathrm{~nm}$ and PI fluorescence was collected at $670 / 14 \mathrm{~nm}$ with excitation at $488 \mathrm{~nm}$. For the detection of apoptotic events, the percentage of the population was evaluated on single cells, which are positive for AV-FITC or PI, using the FlowJoV10 analysis software (FlowJo LLC, USA).

Cell cycle analysis was performed by measuring the changing amount of DNA associated with each phase of the cell cycle. Cellular DNA was labelled with DNA binding fluorochrome and subsequent fluorescence was measured to determine the relative DNA content and cell cycle position. Briefly, after harvesting the cells as described above, the cell pellets were fixed with $1 \mathrm{~mL} 70 \%$ ethanol overnight at $-20^{\circ} \mathrm{C}$. Cells were then pelleted at 2,500 $\mathrm{g} / 5 \mathrm{~min}$ and washed with $1 \mathrm{~mL}$ phosphate-citrate buffer $\left(0.2 \mathrm{M} \mathrm{Na}_{2} \mathrm{HPO}_{4}, 0.1 \mathrm{M}\right.$ citric acid, $\mathrm{pH}$ 7.8). The cell pellet was resuspended in $100 \mu \mathrm{L}$ RNase A (100 $\mu \mathrm{g} / \mathrm{mL}$ in PBS) and incubated for $15 \mathrm{~min}$ at $37{ }^{\circ} \mathrm{C}$ before adding $400 \mu \mathrm{L}$ of PI solution ( $50 \mu \mathrm{g} / \mathrm{mL}$ in PBS) directly to it. After $1 \mathrm{~h}$ incubation in the dark at room temperature, the DNA content was analysed as PI fluorescence emission at $610 \mathrm{~nm}$ using the $561 \mathrm{~nm}$ laser on the BD Fortessa analyser. Cell cycle phases were evaluated using the cell cycle module of the analysing software FlowJo-V10.

\section{Statistical Analysis}

All experiments were repeated independently at least three times. $\mathrm{IC}_{50}$ values of compounds were analysed using GraphPad Prism 7 using non-linear sigmoidal curve fitting with the normalized response. In the case of Oxaliplatin, the Excel add-in ed50v10 was used as this gave better curve fitting for obtaining the $\mathrm{IC}_{50}$. Statistical differences were analysed using one-way ANOVA followed by Dunnett's post-hoc analysis or Student's t-test using GraphPad Prism 7 XML Project (GraphPad Sofware Inc. San Diego, USA). Significant differences were defined as $p<0.05$. Excess Over Bliss (EOB) analysis was performed to determine the drug combinations effect at each combination dose 
according to Liu et al. (25), where an EOB score $>0$ is considered synergism, $=0$ independent/additive, $<0$ antagonism.

\section{Results}

Idebenone decreased viable cell number in glioblastoma cells and enhanced the anti-tumour effects of Temozolomide and Oxaliplatin

The effects of increasing concentrations of IDE on the viable cell number of U373MG and U87MG cells were determined using the MTT assay (Fig. 2A,B). At concentrations of IDE $\geq 20 \mu \mathrm{M}$, a statistically significant decrease in viable cell number was observed for both cell lines at almost all exposure times compared to untreated controls. The half maximal inhibitory concentrations $\left(\mathrm{IC}_{50}\right)$ at $48 \mathrm{~h}$ were $84.5 \pm 5.2 \mu \mathrm{M}$ for $\mathrm{U} 373 \mathrm{MG}$ and $74.4 \pm 2.7 \mu \mathrm{M}$ for U87MG. At longer exposure times, IDE became increasingly toxic with less than $30 \%$ of viable cells remaining after $96 \mathrm{~h}$ exposure at $50 \mu \mathrm{M}$ ( $\mathrm{IC}_{50}$ for $\mathrm{U} 373 \mathrm{MG}$ at 72 and $96 \mathrm{~h}$ are $31.3 \pm 1.9 \mu \mathrm{M}$ and $41.1 \pm 3.1 \mu \mathrm{M}$ respectively, while those for U87MG are $38.7 \pm 1.7 \mu \mathrm{M}$ and $26.6 \pm 1.8 \mu \mathrm{M}$ respectively).

In order to compare the effects of IDE with known anti-cancer agents, cells were also exposed to Temozolomide (TMZ) and Oxaliplatin (OX) for 48 h (Fig. 2C,D). Exposure to oxaliplatin lead to a statistically significant decrease in U87MG viable cell number compared to untreated cells at concentrations $\geq 250 \mu \mathrm{M}$ while in U373MG cells this was observed starting from $350 \mu \mathrm{M}$ (Fig. 2C). The $\mathrm{IC}_{50}$ for $\mathrm{U} 87 \mathrm{MG}$ and $\mathrm{U} 373 \mathrm{MG}$ are $342.4 \pm 2.4 \mu \mathrm{M}$ and $476.8 \pm 12.4 \mu \mathrm{M}$ respectively, suggesting that U373MG cells are more resistant to OX. However, both these values are about five times higher compared to those obtained for IDE which are $>70 \mu \mathrm{M}$ for both cell lines. TMZ had little effect in both cell lines (Fig. 2D). The $\mathrm{IC}_{50}$ was $>500 \mu \mathrm{M}$ for both cell lines which is seven times greater than that of IDE. Thus under our experimental conditions, IDE exhibits greater toxicity than both known anti-cancer agents alone and U373MG cells are more resistant to these drug treatments than U87MG cells. Others have also reported that U373MG cells are more resistant to drug treatment which is consistent with our data $(26,27)$.

Since combining drugs is one of the major strategies used for improving clinical outcomes of GB (28), we explored whether IDE could modulate the effects of TMZ or OX. In the case of U87MG cells, the combination of IDE and OX lead to a greater decrease in cell viability than either IDE or OX alone. However, the results of EOB analysis reported in Fig. 3 suggest that this combination does not have impressive synergism since all values are less than 0.1. In U373MG cells, the combination of $50 \mu \mathrm{M}$ IDE and OX also lead to a greater decrease than OX alone, but not to IDE alone (Fig. 3A,B). The co-presence of OX in this case seems to increase the number of viable cells compared to IDE alone. In fact, this combination appears to have an antagonistic effect according to EOB analysis. When IDE was combined with TMZ, a greater dose-dependent reduction (20-50\% decrease) in cell 
viability was also observed than when either were used alone in both cells lines (Fig. 3C,D), indicating a synergistic effect, albeit unimpressive, as found by EOB analysis.

\section{Idebenone inhibited growth of glioblastoma cells and affected their clonogenic and migratory capacity}

To determine the effects of IDE on cell growth, three concentrations corresponding to a low, medium and relatively high dose $(10,25,50 \mu \mathrm{M})$ of IDE were chosen based on the results reported in Fig. 2A,B (48 h). There was a decrease in total cell number for both cell lines with increasing concentrations of IDE (Fig. 4). In the case of U373MG cells, IDE appears to have a cytostatic effect, especially at $50 \mu \mathrm{M}$ since the cell number in its presence after $48 \mathrm{~h}$ incubation was almost identical as before IDE addition at time 0 (no growth). Instead for U87MG cells, IDE resulted more growth inhibitory since the cell number was reduced after IDE addition but always higher than the starting cell number. In the presence of IDE there was also a modest increase in trypan-blue positive staining indicating increased cell death in the presence of 25 and $50 \mu \mathrm{M}$ IDE after $48 \mathrm{~h}$ (Table 1). This increase is consistent with the trend observed with the MTT assay.

The effects of IDE on cell survival were also assessed. Treatment of glioblastoma cells with IDE reduced the surviving fraction in a dose-dependent manner. After the two-week incubation period hardly any colonies were observed in cells treated with $50 \mu \mathrm{M}$ IDE (Fig. 5A,B). Since the number of colonies is a reliable indicator of the survival potential of these cells, the results indicate that IDE at concentrations $\geq 25 \mu \mathrm{M}$ drastically reduces the ability of glioblastoma cells to survive.

Glioblastomas are known to be highly invasive and infiltrative tumours which are hallmarks of this type of disease, therefore the possible anti-migratory effect of IDE using the wound healing assay was also investigated $(29,30)$. In untreated cells, after $24 \mathrm{~h}$ and $48 \mathrm{~h}$ cells migrated into the wound gap reducing its surface area (Fig. 6A). In the presence of 10 and $25 \mu \mathrm{M}$ IDE however, cell migration diminished by $45 \%$ and $65 \%$ respectively for U373MG cells and by $5 \%$ and $34 \%$ for U87MG cells respectively, at $24 \mathrm{~h}$ (Fig. 6B,C). At $48 \mathrm{~h}$, IDE at both concentrations and in both cell lines significantly reduced cell migration compared to the untreated control at the same time point. The U87MG cells were more migratory than U373MG cells in accordance with the observation of others on these two cell lines $(31,32)$.

\section{Idebenone reduced the expression of caspase-3 and p21 inducing apoptosis and cell-cycle arrest}

The next question was does IDE induce the effects observed through cell cycle dysregulation and/or apoptosis induction? To examine this, the expression of p21 and caspase-3 respectively, were examined by western immunoblotting (Fig. 7). Under our experimental conditions IDE does not seem to exert its effects via apoptosis, at least not in U87MG cells. In these cells, caspase-3 is more expressed than in U373MG cells and there was no significant difference compared to the untreated 
control. This was also confirmed by flow cytometry analysis (Fig. 8A,B) using dual staining with Annexin V/PI where no appreciable differences were observed between the control and IDE treated cells. Camptothecin used as positive control, did however induce apoptosis as can be observed by the significant increase in cells in late apoptosis compared to the control. In U373MG cells a decline in caspase-3 protein expression was evident and significant at $50 \mu \mathrm{M}$ IDE (Fig. 7B). This finding was confirmed by flow cytometry (Fig. 8C,D) which showed that IDE at $25 \mu \mathrm{M}$ and $50 \mu \mathrm{M}$ significantly increased the percentage of early apoptotic cells by almost 2 -fold compared to the untreated control as well as the percentage of cells in late apoptosis at the highest concentration. From the results shown in Fig. 7A and 7C, it also appears that IDE affects the cell cycle since in both cell lines there was a decreasing trend in expression of p21 with increasing concentration of IDE. This is especially the case in U373MG cells which is consistent with the flow cytometry data showing single staining with PI for DNA cell cycle content and distribution (Fig. 9A,B). In this cell line, a significant dose-dependent decrease in cell population in the G1 phase (54\% and $42 \%$ at $25 \mu \mathrm{M}$ and $50 \mu \mathrm{M}$ IDE respectively vs $66 \%$ of control) and 1.5 to 2 -fold increase in the S phase (31\% and $41 \%$ at $25 \mu \mathrm{M}$ and $50 \mu \mathrm{M}$ IDE respectively vs $21 \%$ of control) were observed in the presence of IDE (Fig. 9B). In U87MG cells, as observed for caspase-3, p21 was more expressed compared to U373MG cells. However, despite the significant decrease in p21 expression in these cells at $50 \mu \mathrm{M}$, the DNA distribution analysed by flow cytometry revealed no apparent changes in the presence of IDE in three independent experiments (results not shown).

\section{Discussion}

The main purpose of this study was to investigate the potential anti-cancer effect of IDE on two human glioblastoma cells lines. GB is one of the most resistant tumours to conventional cytotoxic therapies therefore current studies concentrate on the development of novel agents for use either alone or in combination with standard chemotherapy and radiotherapy. In this study, we demonstrate that IDE decreased cell viability in a time and concentration dependent manner and that it was cytotoxic at concentrations similar to those reported by others on both human and non-human cancer cells $(18,19,33,34)$. Furthermore, in a separate study IDE had no effect on a normal cell line consisting of colonocytes (CCD841CON) whereas it proved to be cytotoxic in a colorectal cancer cell line (SW480) (results not shown). Interestingly, when IDE was co-administered with the two well-known anti-cancer agents, TMZ and OX, a greater decrease in cell viability was observed in both cell lines, especially with TMZ. This improved effect resulted marginally synergistic. Since IDE appears to enhance the cytotoxic effects of TMZ, this novel combination for GB therapy merits further investigation, especially as combinations of other drugs and natural compounds with TMZ are being explored continuously $(27,31,35-40)$. OX has been occasionally used for treating GB but limited due to its side effects (41). However, it was chosen in this study for comparison with IDE, since there 
have been indications recently for repurposing platinum-based chemotherapies for multi-modal treatment of GB. Hence it could be more widely used for GB treatment in the future (42). Besides this aspect, IDE also proved to be more potent than both cytotoxics, with $\mathrm{IC}_{50}$ value at least five times lower than those of the known drugs. The reduced number of colonies in the gold standard colony forming assay, provided further evidence of the growth inhibitory and hence survival effects of IDE. To the best of our knowledge, this is the first report showing the ability of IDE to hamper with cell survival in the long-term. In the context of preventing recurrence this is important, as the capacity for unlimited proliferation of all stem cells must be eradicated. In this study we also established that IDE inhibits cell migration as previously observed in prostate cancer cells (19). This antimigratory/metastatic effect of IDE on GB cells could help to contain spreading of a GB tumour in vivo.

In the attempt to address the possible mechanisms underlying the effects displayed by IDE on glioma cells, we found that apoptosis is probably not a major pathway responsible for the above outcomes, at least not in U87MG cells where no major decline in pro-caspase-3 was observed nor was there any indication from the flow cytometric data. Caspase- 3 belongs to the executioner family of cysteine-aspartic acid proteases (caspases), and plays a dominant role in the hallmark caspase cascade characteristic of the apoptotic pathway (43). Upon activation it is cleaved into its active $17 \mathrm{kDa}$ and $12 \mathrm{kDa}$ fragments which leads to a concomitant decrease in intensity of the uncleaved band at $32 \mathrm{kDa}$ during immunoblot analysis. This could explain the dose-dependent decrease in protein expression observed in U373MG cells in the presence of IDE. Indeed, in U373MG cells IDE appears to induce modest apoptosis as also confirmed by Annexin/PI staining analysis using flow cytometry. These results are in accordance with two previous reports on the direct effects of IDE on cancer cells which both describe an apoptotic effect of IDE $(18,19)$. Seo et al. attribute their observations to the fact that IDE blocks the ANO1 calcium-chloride channel, but it has no effect on cancer cells which do not express ANO1 (19). However, in U87MG cells we failed to observe evidence of IDE-induced apoptosis and this could be due to the p53 status of the two cell lines. p53 is a well-known tumour suppressor protein which when active, induces a number of genes linked to diverse functions such as cell cycle regulation, DNA repair mechanisms and those related to apoptosis (44). U87MG cells have a wild-type p53 gene but do not express the functional protein to any measurable extent because of Mdm2 overexpression which destabilizes it (45), whereas U373MG cells have a mutant p53 gene (44). Lack of p53 activity in U87MG cells could thus prevent the induction of p53-dependent apoptosis whether IDE is present or not, explaining our results. In the case of U373MG, dysfunctional p53 activity due to the mutated gene would make these cells more sensitive to high concentrations of IDE which could then respond by apoptosis, as indicated by the decreased expression of pro-caspase3 at $50 \mu \mathrm{M}$ IDE and by the flow cytometric analysis. This divergent apoptotic response to IDE possibly due to the p53 status of the two cell lines, is similar to that described by Datta et al. on the same cells in the presence of cisplatin (46). The higher protein levels of caspase-3 and p21 expressed 
in U87MG cells compared to U373MG cells may also reflect this different status, similarly to the observations by Ravizza et al. for p21 (27).

It is more likely that under our experimental conditions, IDE exerts its anti-proliferative effects by interfering with cell cycle regulation, since in both cell lines a decline in protein expression of the cyclin-dependent kinase (CDK) inhibitor, p21 (known as p21WAF1/Cip1) was evident especially at high concentrations. This protein is uniquely positioned in the cell cycle to function as both a sensor and an effector of multiple anti-proliferative signals in response to a variety of cellular and environmental signals to promote tumour suppressor activities, both dependently and independently of the classical p53 tumour suppressor pathway. Usually, it is assumed that p21 downregulation or repression increases cell cycle progression and proliferation due to disinhibition of cyclin/cdk complexes (47). However, this is not always the case as indicated by several reports in which p21 functions as a positive cell cycle regulator. Indeed, in U373MG cells we observed using flow cytometry, a dose-related increase in cell population in the $\mathrm{S}$ phase and a concomitant decrease in cells in the G1 phase of the cell cycle, suggesting that IDE is responsible for accumulation of cells in $\mathrm{S}$ phase. A similar $\mathrm{S}$ phase arrest concomitant with $\mathrm{p} 21$ downregulation has also been observed by others in human cells under different treatment regimes (48-50). During S phase, replication can cease in response to DNA damage or stress to the replication process. However, while the former response induces arrest through different mechanisms involving ATM protein kinases and invoking p53 and p21 response, the response to replicative stress arrests all cells regardless of p53 status and is not accompanied by p21 induction (51). Since we do not observe IDE-induced p21 in GB cells, we expect that IDE is affecting them mainly through replicative stress. The correlation between reduced expression of p21 and impairment of cell proliferation as observed in our study has been shown in several cell models ranging from HaCaT keratinocytes (52), smooth muscle cells (53), endothelial cells (54), colon and liver cancer cells $(55,56)$ exposed to different stimuli although the reason for this has not always been clarified. The mechanism by which IDE downregulates p21 in glioma cells remains to be elucidated. However, the evidence so far suggests that in U373MG cells, IDE-induced S-phase arrest is linked to p21 down-regulation and that this plays an important part in IDE-induced apoptosis. This is supported by the fact that in several systems p21 down-regulation has been shown to trigger apoptosis (57-59). In U87MG cells, despite observing p21 decrease in the presence of IDE at $50 \mu \mathrm{M}$, we could not link this to any changes in DNA cell cycle distribution, suggesting that our observations are cell-line specific. These differential responses between the two cell lines may depend on their p53 status as recently reviewed by Georgakilas (60) who depicts p21 as an onco-suppressor or an onco-promotor depending on cell type, cellular localization, p53 status, and the type and level of genotoxic stress. The fact that IDE downregulates p21 expression in U373MG and U87MG cells which are p53-deficient/mutant, implies that IDE could repress the oncogenic potential of these cells via p21 inhibition. Repression of p21 by IDE could also explain the anti-migratory effect observed in this study, since p21 appears to be essential for cell migration as reported in bladder cancer cells 
induced by the inflammatory cytokine IL-20 (61). Further investigations are clearly required to understand mechanistically the effects of IDE observed in this research.

Overall, the present study demonstrates that IDE has potential as an anti-proliferative agent for GB by interfering with several features of glioma pathogenesis such as proliferation and migration. The human safety of IDE is well-established and a daily dose of $60 \mathrm{mg} / \mathrm{kg} / \mathrm{day}$ has been shown to reach a transient concentration in plasma equivalent to $29.6 \mu \mathrm{M}$ (62). This is a concentration close to those used in this study which were effective $(25-50 \mu \mathrm{M})$. Recently, the repurposing of existing drugs has attracted considerable attention (63) because it is advantageous, in time and cost saving. Therefore IDE, besides its current use in mitochondrial related-neuromuscular and neurodegenerative diseases, could be repurposed for aiding cancer treatments especially as it can cross the BBB. For example, its analogue Coenzyme Q10 has already been reported to be a promising candidate either alone or in combination for prevention and treatment of breast cancer (64). Atovaquone, another CoQ10 analogue and an FDA-approved anti-malarial drug, is another example which is being considered for repurposing because of its anti-proliferative effect against MCF7 Cancer Stem-like Cells (65).The future treatment of malignant gliomas will likely involve synergistic combinations of agents aimed at different pathways in the molecular pathogenesis of this type of cancer. In this context, the results of the present study on IDE appear promising providing the preliminary experimental basis for exploring it further.

Conflict of Interest. The authors declare that there are no competing interests associated with the manuscript.

Funding. E.D. was funded by an internal research grant from the Polytechnic University of the Marche provided by MIUR (Italian Ministry of University and Research). Funding for FACS experiments was provided by grant code no. RO10014-13 from the Cell, Developmental and Cancer Biology Research Programme, University of Aberdeen.

Author contributions. E.D. and H.M.W. designed the study. E.D. performed the experiments, interpreted the data and wrote the manuscript. H.M.W. interpreted the data and revised the manuscript. R.Y. helped with FACS experiments, analysis and interpretation. All authors have read and approved the final version.

\section{References}

(1) Van Meir EG, Hadjipanayis CG, Norden AD, Shu HK, Wen PY, Olson JJ. Exciting new advances in neuro-oncology: the avenue to a cure for malignant glioma. CA Cancer J Clin 2010 MayJun;60(3):166-193.

(2) Anderson E, Grant R, Lewis SC, Whittle IR. Randomized Phase III controlled trials of therapy in malignant glioma: where are we after 40 years? Br J Neurosurg 2008 Jun;22(3):339-349. 
(3) Mandel JJ, Yust-Katz S, Patel AJ, Cachia D, Liu D, Park M, et al. Inability of positive phase II clinical trials of investigational treatments to subsequently predict positive phase III clinical trials in glioblastoma. Neuro Oncol 2017 Jul 31.

(4) Bianco J, Bastiancich C, Jankovski A, des Rieux A, Preat V, Danhier F. On glioblastoma and the search for a cure: where do we stand? Cell Mol Life Sci 2017 Jul;74(13):2451-2466.

(5) Deeken JF, Loscher W. The blood-brain barrier and cancer: transporters, treatment, and Trojan horses. Clin Cancer Res 2007 Mar 15;13(6):1663-1674.

(6) Nagai Y, Yoshida K, Narumi S, Tanayama S, Nagaoka A. Brain distribution of idebenone and its effect on local cerebral glucose utilization in rats. Arch Gerontol Geriatr 1989 May;8(3):257-272.

(7) Torii H, Yoshida K, Kobayashi T, Tsukamoto T, Tanayama S. Disposition of idebenone (CV2619), a new cerebral metabolism improving agent, in rats and dogs. J Pharmacobiodyn 1985 Jun;8(6):457-467.

(8) Gutzmann H, Kuhl KP, Hadler D, Rapp MA. Safety and efficacy of idebenone versus tacrine in patients with Alzheimer's disease: results of a randomized, double-blind, parallel-group multicenter study. Pharmacopsychiatry 2002 Jan;35(1):12-18.

(9) Gillis JC, Benefield P, McTavish D. Idebenone. A review of its pharmacodynamic and pharmacokinetic properties, and therapeutic use in age-related cognitive disorders. Drugs Aging 1994 Aug;5(2):133-152.

(10) Schulz JB, Di Prospero NA, Fischbeck K. Clinical experience with high-dose idebenone in Friedreich ataxia. J Neurol 2009 Mar;256 Suppl 1:42-45.

(11) Brandsema JF, Stephens D, Hartley J, Yoon G. Intermediate-dose idebenone and quality of life in Friedreich ataxia. Pediatr Neurol 2010 May;42(5):338-342.

(12) McDonald CM, Meier T, Voit T, Schara U, Straathof CS, D'Angelo MG, et al. Idebenone reduces respiratory complications in patients with Duchenne muscular dystrophy. Neuromuscul Disord 2016 Aug;26(8):473-480.

(13) Gueven N. Idebenone for Leber's hereditary optic neuropathy. Drugs Today (Barc) 2016 Mar;52(3):173-181.

(14) Jaber S, Polster BM. Idebenone and neuroprotection: antioxidant, pro-oxidant, or electron carrier? J Bioenerg Biomembr 2015 Apr;47(1-2):111-118.

(15) Erb M, Hoffmann-Enger B, Deppe H, Soeberdt M, Haefeli RH, Rummey C, et al. Features of idebenone and related short-chain quinones that rescue ATP levels under conditions of impaired mitochondrial complex I. PLoS One 2012;7(4):e36153.

(16) Kutz K, Drewe J, Vankan P. Pharmacokinetic properties and metabolism of idebenone. J Neurol 2009 Mar;256 Suppl 1:31-35.

(17) Gueven N, Woolley K, Smith J. Border between natural product and drug: comparison of the related benzoquinones idebenone and coenzyme Q10. Redox Biol 2015;4:289-295. 
(18) Tai KK, Pham L, Truong DD. Idebenone induces apoptotic cell death in the human dopaminergic neuroblastoma SHSY-5Y cells. Neurotox Res 2011 Nov;20(4):321-328.

(19) Seo Y, Park J, Kim M, Lee HK, Kim JH, Jeong JH, et al. Inhibition of ANO1/TMEM16A Chloride Channel by Idebenone and Its Cytotoxicity to Cancer Cell Lines. PLoS One 2015 Jul 21;10(7):e0133656.

(20) Schmidt L, Kling T, Monsefi N, Olsson M, Hansson C, Baskaran S, et al. Comparative drug pair screening across multiple glioblastoma cell lines reveals novel drug-drug interactions. Neuro Oncol 2013 Nov;15(11):1469-1478.

(21) Berridge MV, Herst PM, Tan AS. Tetrazolium dyes as tools in cell biology: new insights into their cellular reduction. Biotechnol Annu Rev 2005;11:127-152.

(22) Franken NA, Rodermond HM, Stap J, Haveman J, van Bree C. Clonogenic assay of cells in vitro. Nat Protoc 2006;1(5):2315-2319.

(23) Valster A, Tran NL, Nakada M, Berens ME, Chan AY, Symons M. Cell migration and invasion assays. Methods 2005 Oct;37(2):208-215.

(24) Damiani E, Puebla-Osorio N, Gorbea E, Ullrich SE. Platelet-Activating Factor Induces Epigenetic Modifications in Human Mast Cells. J Invest Dermatol 2015 Dec;135(12):3034-3040.

(25) Liu Q, Yin X, Languino LR, Altieri DC. Evaluation of drug combination effect using a Bliss independence dose-response surface model. Stat Biopharm Res 2018 Feb:10(2):112-122.

(26) Li S, Chou AP, Chen W, Chen R, Deng Y, Phillips HS, et al. Overexpression of isocitrate dehydrogenase mutant proteins renders glioma cells more sensitive to radiation. Neuro Oncol 2013 Jan;15(1):57-68.

(27) Ravizza R, Cereda E, Monti E, Gariboldi MB. The piperidine nitroxide Tempol potentiates the cytotoxic effects of temozolomide in human glioblastoma cells. Int J Oncol 2004 Dec;25(6):1817-1822.

(28) Ohka F, Natsume A, Wakabayashi T. Current trends in targeted therapies for glioblastoma multiforme. Neurol Res Int 2012;2012:878425.

(29) Hanahan D, Weinberg RA. Hallmarks of cancer: the next generation. Cell 2011 Mar 4;144(5):646-674.

(30) Kramer N, Walzl A, Unger C, Rosner M, Krupitza G, Hengstschlager M, et al. In vitro cell migration and invasion assays. Mutat Res 2013 Jan-Mar;752(1):10-24.

(31) Li C, Zhou Y, Peng X, Du L, Tian H, Yang G, et al. Sulforaphane inhibits invasion via activating ERK1/2 signaling in human glioblastoma U87MG and U373MG cells. PLoS One 2014 Feb 28;9(2):e90520.

(32) Jung JS, Ahn JH, Le TK, Kim DH, Kim HS. Protopanaxatriol ginsenoside Rh1 inhibits the expression of matrix metalloproteinases and the in vitro invasion/migration of human astroglioma cells. Neurochem Int 2013 Aug;63(2):80-86. 
(33) Wempe MF, Lightner JW, Zoeller EL, Rice PJ. Investigating idebenone and idebenone linoleate metabolism: in vitro pig ear and mouse melanocyte studies. J Cosmet Dermatol 2009 Mar;8(1):63-73.

(34) Shah SM, Ashtikar M, Jain AS, Makhija DT, Nikam Y, Gude RP, et al. LeciPlex, invasomes, and liposomes: A skin penetration study. Int J Pharm 2015 Jul 25;490(1-2):391-403.

(35) Dinnes J, Cave C, Huang S, Milne R. A rapid and systematic review of the effectiveness of temozolomide for the treatment of recurrent malignant glioma. $\mathrm{Br} \mathrm{J}$ Cancer $2002 \mathrm{Feb}$ 12;86(4):501-505.

(36) Serwer LP, James CD. Challenges in drug delivery to tumors of the central nervous system: an overview of pharmacological and surgical considerations. Adv Drug Deliv Rev 2012 May 15;64(7):590-597.

(37) Pazhouhi M, Sariri R, Rabzia A, Khazaei M. Thymoquinone synergistically potentiates temozolomide cytotoxicity through the inhibition of autophagy in U87MG cell line. Iran J Basic Med Sci 2016 Aug;19(8):890-898.

(38) Atif F, Patel NR, Yousuf S, Stein DG. The Synergistic Effect of Combination Progesterone and Temozolomide on Human Glioblastoma Cells. PLoS One 2015 Jun 25;10(6):e0131441.

(39) Woo SR, Ham Y, Kang W, Yang H, Kim S, Jin J, et al. KML001, a telomere-targeting drug, sensitizes glioblastoma cells to temozolomide chemotherapy and radiotherapy through DNA damage and apoptosis. Biomed Res Int 2014;2014:747415.

(40) Ramirez YP, Weatherbee JL, Wheelhouse RT, Ross AH. Glioblastoma multiforme therapy and mechanisms of resistance. Pharmaceuticals (Basel) 2013 Nov 25;6(12):1475-1506.

(41) Avgeropoulos NG, Batchelor TT. New treatment strategies for malignant gliomas. Oncologist 1999;4(3):209-224.

(42) Roberts NB, Wadajkar AS, Winkles JA, Davila E, Kim AJ, Woodworth GF. Repurposing platinum-based chemotherapies for multi-modal treatment of glioblastoma. Oncoimmunology 2016 Aug 19;5(9):e1208876.

(43) McIlwain DR, Berger T, Mak TW. Caspase functions in cell death and disease. Cold Spring Harb Perspect Biol 2013 Apr 1;5(4):a008656.

(44) Van Meir EG, Kikuchi T, Tada M, Li H, Diserens AC, Wojcik BE, et al. Analysis of the p53 gene and its expression in human glioblastoma cells. Cancer Res 1994 Feb 1;54(3):649-652.

(45) Weller M, Rieger J, Grimmel C, Van Meir EG, De Tribolet N, Krajewski S, et al. Predicting chemoresistance in human malignant glioma cells: the role of molecular genetic analyses. Int $\mathbf{J}$ Cancer 1998 Dec 18;79(6):640-644.

(46) Datta K, Shah P, Srivastava T, Mathur SG, Chattopadhyay P, Sinha S. Sensitizing glioma cells to cisplatin by abrogating the p53 response with antisense oligonucleotides. Cancer Gene Ther 2004 Aug;11(8):525-531. 
(47) Xiong Y, Hannon GJ, Zhang H, Casso D, Kobayashi R, Beach D. P21 is a Universal Inhibitor of Cyclin Kinases. Nature 1993 Dec 16;366(6456):701-704.

(48) Olivero OA, Tejera AM, Fernandez JJ, Taylor BJ, Das S, Divi RL, et al. Zidovudine induces Sphase arrest and cell cycle gene expression changes in human cells. Mutagenesis 2005 Mar;20(2):139-146.

(49) Borel F, Lacroix FB, Margolis RL. Prolonged arrest of mammalian cells at the G1/S boundary results in permanent S phase stasis. J Cell Sci 2002 Jul 15;115(Pt 14):2829-2838.

(50) Reyes-Reyes EM, Jin Z, Vaisberg AJ, Hammond GB, Bates PJ. Physangulidine A, a withanolide from Physalis angulata, perturbs the cell cycle and induces cell death by apoptosis in prostate cancer cells. J Nat Prod 2013 Jan 25;76(1):2-7.

(51) Gottifredi V, Shieh S, Taya Y, Prives C. p53 accumulates but is functionally impaired when DNA synthesis is blocked. Proc Natl Acad Sci U S A 2001 Jan 30;98(3):1036-1041.

(52) Chen A, Huang X, Xue Z, Cao D, Huang K, Chen J, et al. The Role of p21 in Apoptosis, Proliferation, Cell Cycle Arrest, and Antioxidant Activity in UVB-Irradiated Human HaCaT Keratinocytes. Med Sci Monit Basic Res 2015 Apr 30;21:86-95.

(53) Kavurma MM, Khachigian LM. Sp1 inhibits proliferation and induces apoptosis in vascular smooth muscle cells by repressing p21WAF1/Cip1 transcription and cyclin D1-Cdk4p21WAF1/Cip1 complex formation. J Biol Chem 2003 Aug 29;278(35):32537-32543.

(54) Noseda M, Chang L, McLean G, Grim JE, Clurman BE, Smith LL, et al. Notch activation induces endothelial cell cycle arrest and participates in contact inhibition: role of p21Cip1 repression. Mol Cell Biol 2004 Oct;24(20):8813-8822.

(55) Arango D, Mariadason JM, Wilson AJ, Yang W, Corner GA, Nicholas C, et al. c-Myc overexpression sensitises colon cancer cells to camptothecin-induced apoptosis. Br J Cancer 2003 Nov 3;89(9):1757-1765.

(56) Wong SH, Zhao Y, Schoene NW, Han CT, Shih RS, Lei KY. Zinc deficiency depresses p21 gene expression: inhibition of cell cycle progression is independent of the decrease in p21 protein level in HepG2 cells. Am J Physiol Cell Physiol 2007 Jun;292(6):C2175-84.

(57) Fan X, Liu Y, Chen JJ. Down-regulation of p21 contributes to apoptosis induced by HPV E6 in human mammary epithelial cells. Apoptosis 2005 Jan;10(1):63-73.

(58) Bunz F, Hwang PM, Torrance C, Waldman T, Zhang Y, Dillehay L, et al. Disruption of p53 in human cancer cells alters the responses to therapeutic agents. J Clin Invest 1999 Aug;104(3):263269.

(59) Sak A, Wurm R, Elo B, Grehl S, Pottgen C, Stuben G, et al. Increased radiation-induced apoptosis and altered cell cycle progression of human lung cancer cell lines by antisense oligodeoxynucleotides targeting p53 and p21(WAF1/CIP1). Cancer Gene Ther 2003 Dec;10(12):926-934. 
(60) Georgakilas AG, Martin OA, Bonner WM. p21: A Two-Faced Genome Guardian. Trends Mol Med 2017 Apr;23(4):310-319.

(61) Lee EJ, Lee SJ, Kim S, Cho SC, Choi YH, Kim WJ, et al. Interleukin-5 enhances the migration and invasion of bladder cancer cells via ERK1/2-mediated MMP-9/NF-kappaB/AP-1 pathway: involvement of the p21WAF1 expression. Cell Signal 2013 Oct;25(10):2025-2038.

(62) Di Prospero NA, Sumner CJ, Penzak SR, Ravina B, Fischbeck KH, Taylor JP. Safety, tolerability, and pharmacokinetics of high-dose idebenone in patients with Friedreich ataxia. Arch Neurol 2007 Jun;64(6):803-808.

(63) Pantziarka P, Bouche G, Meheus L, Sukhatme V, Sukhatme VP, Vikas P. The Repurposing Drugs in Oncology (ReDO) Project. Ecancermedicalscience 2014 Jul 10;8:442.

(64) Tafazoli A. Coenzyme Q10 in breast cancer care. Future Oncol 2017 May;13(11):1035-1041.

(65) Fiorillo M, Lamb R, Tanowitz HB, Mutti L, Krstic-Demonacos M, Cappello AR, et al. Repurposing atovaquone: targeting mitochondrial complex III and OXPHOS to eradicate cancer stem cells. Oncotarget 2016 Jun 7;7(23):34084-34099.

\section{Legends to Figures}

Figure 1. Chemical structure of Idebenone and the naturally occurring analogue, Coenzyme $Q_{10}$.

Figure 2. Effect of Idebenone, Oxaliplatin and Temozolomide on viable cell number of human glioblastoma cells. U373MG (A) and U87MG (B) cells were exposed to increasing concentrations of Idebenone for $48 \mathrm{~h}, 72 \mathrm{~h}$ or $96 \mathrm{~h}$ and cell-survival was assessed using the MTT assay. U373MG and U87MG cells were exposed to increasing concentrations of either Oxaliplatin (C) or Temozolomide (D) for $48 \mathrm{~h}$ and cell-survival was assessed using the MTT assay. The results are expressed as the percentage of viable cells compared to the control. Data are presented as mean \pm SEM, of at least 24 wells from at least four independent experiments (for Idebenone) and of at least 18 wells from at least three independent experiments for Temozolomide and Oxaliplatin. Statistics was performed using one-way Anova with Dunnett's post-hoc analysis (* $\mathrm{p}<0.05$ vs untreated). Dotted line is set at $50 \%$ to show the $\mathrm{IC}_{50}$.

Figure 3. Effect of Idebenone in combination with anti-cancer agents on viable cell number of human glioblastoma cells. Cells were treated with Idebenone (IDE), Oxaliplatin (OX), Temozolomide (TMZ) singularly and in combination at various concentrations for $48 \mathrm{~h}$ and viability was measured using the MTT assay. (A) U87MG cells in the presence of IDE and OX. (B) U373MG cells in the presence of IDE and OX. (C) U87MG cells in the presence of IDE and TMZ. (D) U373MG cells in the presence of IDE and TMZ. The results are expressed as the percentage of viable cells compared to the control. Data are presented as mean \pm SEM, of at least 18 wells from at least three independent experiments. 
594 Statistics was performed using one-way Anova with Dunnett's post-hoc analysis $\left({ }^{*} \mathrm{p}<0.05\right.$ vs OX or 595 TMZ alone).

596 The values reported above the bars for the combinations are the EOB score values.

597

598

599

600

601

602

603

604

605

606

607

608

609

610

611

612

613

614

615

616

617

618

619

620

621

622

623

624

625

626

627

628

629

Figure 4. Effect of Idebenone on the growth of human glioblastoma cells. U373MG and U87MG cells were exposed to increasing concentrations of Idebenone for $48 \mathrm{~h}$ before counting using a Coulter Counter as described in the Methods section. Dotted line represents cell number prior to Idebenone addition $(0 \mathrm{~h})$ in both cell lines. Data are presented as mean \pm SEM, $n=3$ independent experiments. Statistics was performed using Student's t-test $\left({ }^{*} \mathrm{p}<0.05\right.$ vs untreated $)$.

Figure 5. Effect of increasing concentrations of Idebenone on the clonogenic survival of human glioblastoma cells. U373MG and U87MG cells were seeded in $6 \mathrm{~cm}$ culture dishes at a density of 200 cells/dish (U373MG) and 400 cells/dish (U87MG) and incubated for two weeks in the presence of increasing concentrations of Idebenone. (A) Surviving fraction of colonies analysed two weeks later after staining with crystal violet. (B) Clones produced by U373MG human glioblastoma cells only are shown since those produced by U87MG cells were only visible by light microscopy. The images are representative of at least 3 independent experiments each performed in duplicate. Data are presented as mean \pm SEM, $n=3$ independent experiments. Statistics was performed using the Student's t-test $\left({ }^{*} \mathrm{p}<0.05\right.$ vs untreated).

Figure 6. Effect of Idebenone on migration of human glioblastoma cells. For the wound healing assay, U373MG and U87MG cells were treated with different concentrations of Idebenone and the wound closure was quantified every $24 \mathrm{~h}$ post-wound. (A) Representative photomicrographs (x10) taken at time $0 \mathrm{~h}$ and at $48 \mathrm{~h}$ post-wounding of U373MG and U87MG cells grown in 6-well plates, incubated in the presence of 10 and $25 \mu \mathrm{M}$ Idebenone, are shown. Gap surface area of the scratch/wound were analysed using ImageJ software and are expressed as the $\%$ of the area of time $0 \mathrm{~h}$ in both cell lines (B) U373MG and (C) U87MG. Data are presented as mean $\pm \mathrm{SD}, \mathrm{n}=3$ independent experiments. Statistics was performed using Student's t-test $(\mathrm{p}<0.05),{ }^{*}$ vs respective $0 \mathrm{~h}, \S$ vs untreated at same time point.

Figure 7. Effect of Idebenone on expression of caspase-3 and p21 in human glioblastoma cells. Protein expression was analysed by immunoblotting. (A) p21 and Caspase-3 expression in control and treated cells, $48 \mathrm{~h}$ post-exposure to Idebenone (IDE). $\beta$-actin was used as loading control. The images are representative of three independent experiments. Results on quantification of caspase-3 (B) and p21 (C) protein expression from three independent experiments using ImageJ software. Data are presented as mean \pm SD. Statistics was performed using Student's t-test $(* p<0.05$ vs untreated). 
631 Figure 8. Annexin V-FITC/PI flow cytometric analysis of apoptosis in human glioblastoma cells.

632 U373MG and U87MG cells were treated with different concentrations of Idebenone (IDE) or $1 \mu \mathrm{M}$ 633 Camptothecin (CPT) for $24 \mathrm{~h}$, harvested by trypsinization, stained with annexin V-FITC (AV) and 634 propidium iodide (PI) and then subjected to flow cytometry and analysed. AV-PI-, live cells; AV+PI-, 635 early apoptosis; AV+PI+, late apoptosis; AV-PI+, necrosis. (A) Representative dot plots from one 636 experiment are shown for U87MG cells. (B) Graph showing data collected for U87MG cells from 637 'AV+PI-, AV+PI+ quadrants' from 3 independent experiments. (C) Representative dot plots from one 638 experiment are shown for U373MG cells. (B) Graph showing data collected for U373MG cells from 639 'AV+PI-, $\mathrm{AV}+\mathrm{PI}+$ quadrants' from 3 independent experiments. Data are presented as mean $\pm \mathrm{SEM}$, $640 \mathrm{n}=3$. Statistics was performed using Student's t-test (* $\mathrm{p}<0.05$ vs control).

642 Figure 9. Flow cytometric analysis of cell cycle parameters in human glioblastoma cells. U373MG 643 and U87MG cells were treated with different concentrations of Idebenone (IDE) or $1 \mu \mathrm{M}$ 644 Camptothecin (CPT) for $24 \mathrm{~h}$, harvested by trypsinization, fixed, stained with propidium iodide (PI) 645 and then subjected to flow cytometry and analysed for cell cycle DNA distribution. (A) 646 Representative DNA content histograms from one experiment are shown for U373MG cells. G1 phase 647 (darkest/purple fraction), S phase (lightest/yellow fraction), G2 (grey/green fraction). (B) Graph 648 showing data collected for U373MG cells from the three different fractions of the histograms from 3 649 independent experiments. Data are presented as mean \pm SEM, $n=3$. Statistics was performed using 650 Student's t-test ( ${ }^{*} \mathrm{p}<0.05$ vs control). Data for U87MG cells are not shown as no differences were

651 observed between treated cells and the untreated ones from 3 independent experiments.
652

653

654

655

656

657

658

659

660

661

662

663

664

665

666 
667

668 
Table 1: Number of dead/dying human glioblastoma cells in the presence of Idebenone. U373MG and U87MG cells were exposed to increasing concentrations of Idebenone for $48 \mathrm{~h}$ before the TrypanBlue exclusion assay was performed to determine the no. of dead/dying cells as described in the Methods section. The results are reported as the $\%$ of dead/dying cells over the total cell no. for each treatment. Data are presented as mean $\pm \mathrm{SD}, \mathrm{n}=3$ independent experiments. Statistics was performed using the Student's t-test $\left({ }^{*} \mathrm{p}<0.05\right.$ vs untreated).

\begin{tabular}{|ccc|}
\hline Cell line & Idebenone $(\mu \mathrm{M})$ & $\begin{array}{c}\text { No. of dead/dying cells } \\
\text { (\% of total cell no.) }\end{array}$ \\
\hline \multirow{3}{*}{ U373MG } & 0 & $3.67 \pm 1.15$ \\
& 10 & $7.17 \pm 1.04$ \\
& 25 & $9.83 \pm 2.47$ \\
U87MG & 50 & $15.00 \pm 5.12^{*}$ \\
& 0 & $7.33 \pm 1.15$ \\
& 10 & $8.30 \pm 2.89$ \\
& 25 & $13.60 \pm 3.14^{*}$ \\
& 50 & $17.83 \pm 4.37^{*}$ \\
\hline
\end{tabular}




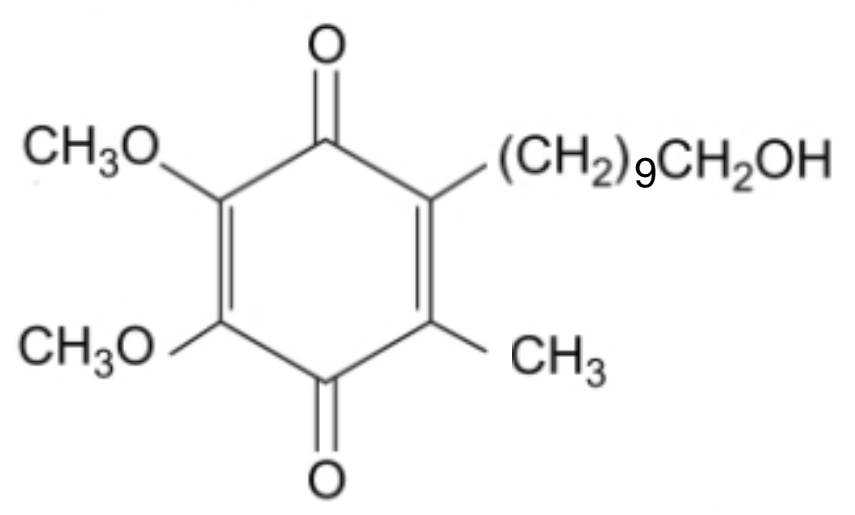

Idebenone

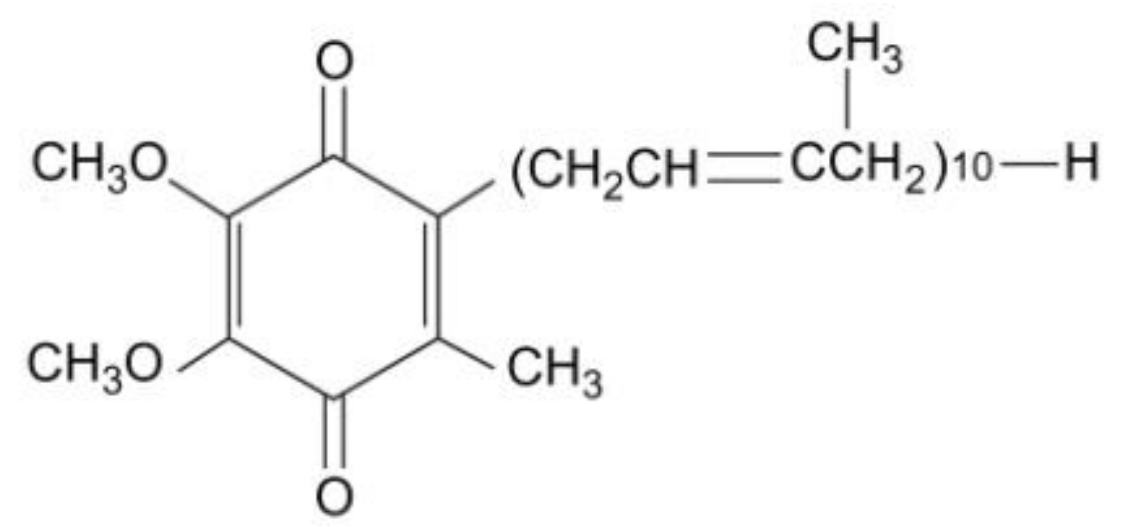

Coenzyme $Q_{10}$ 

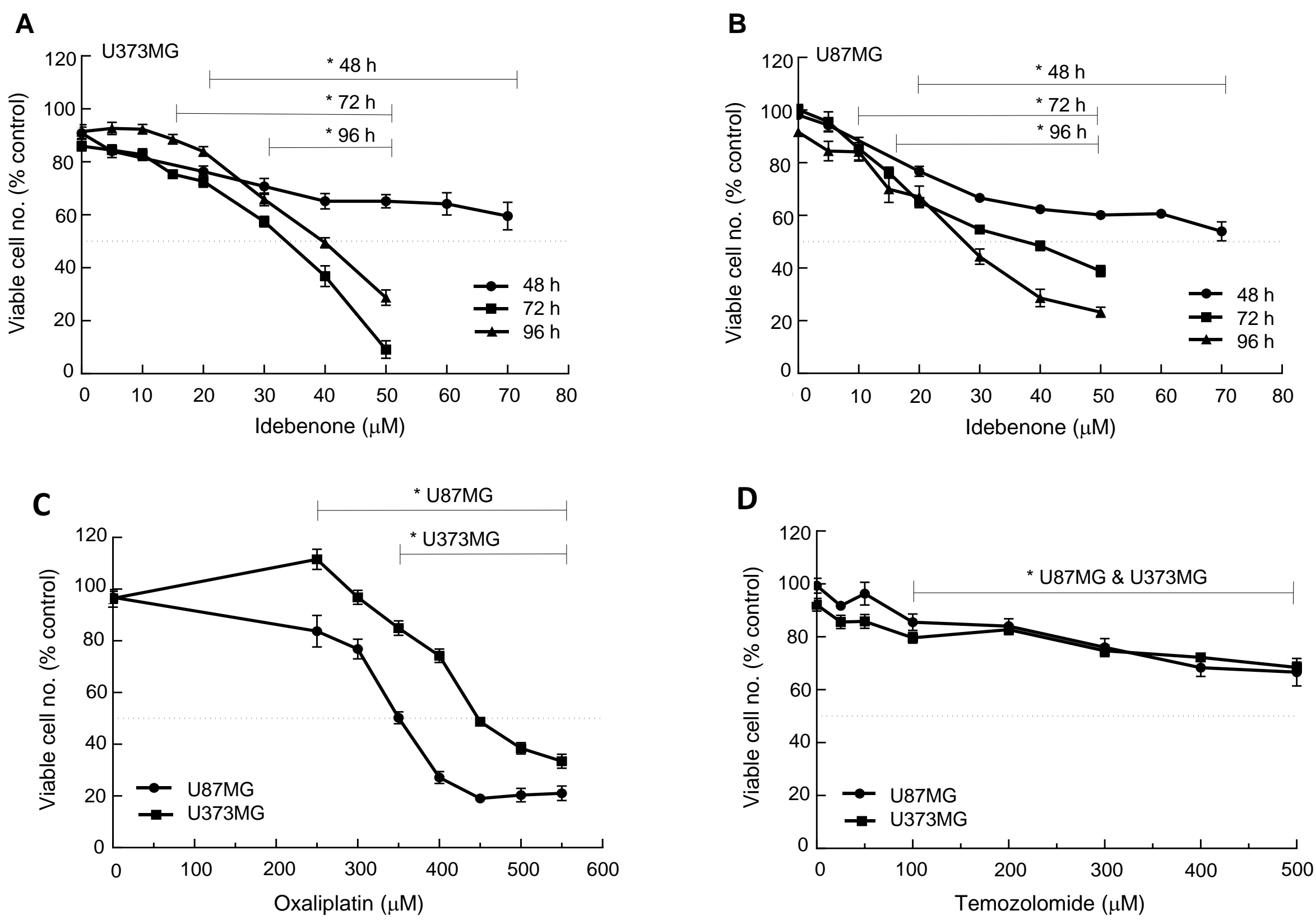

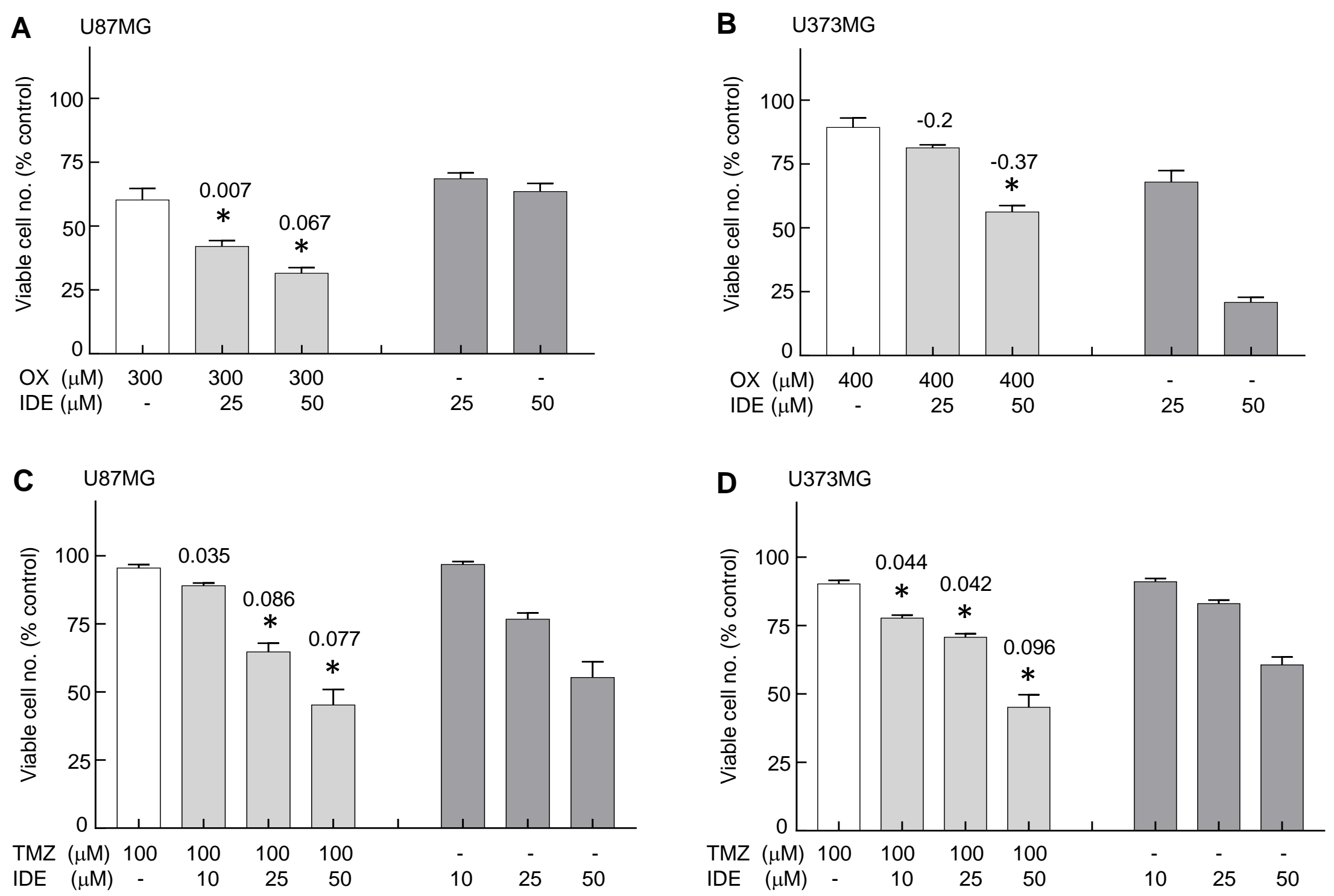


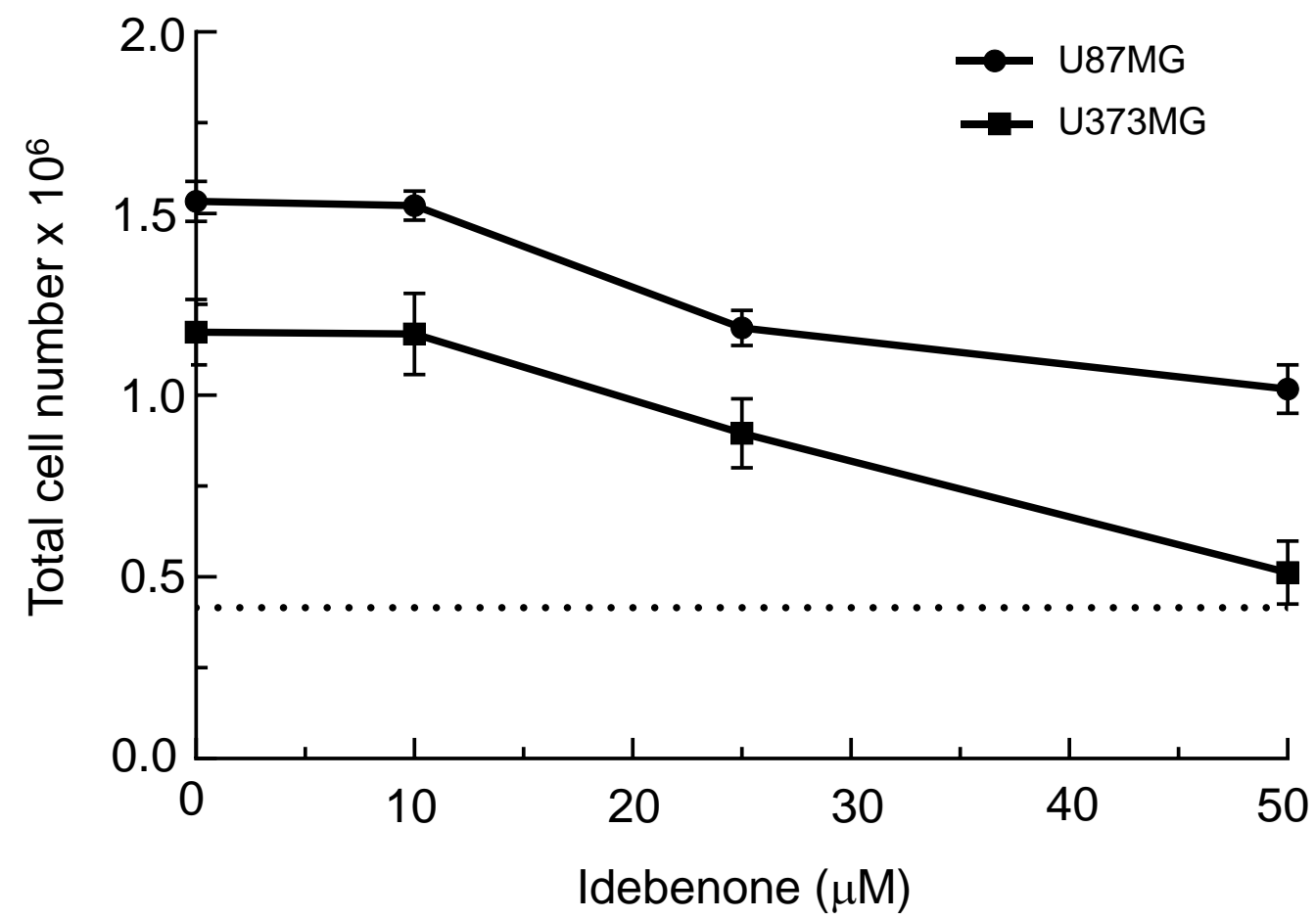



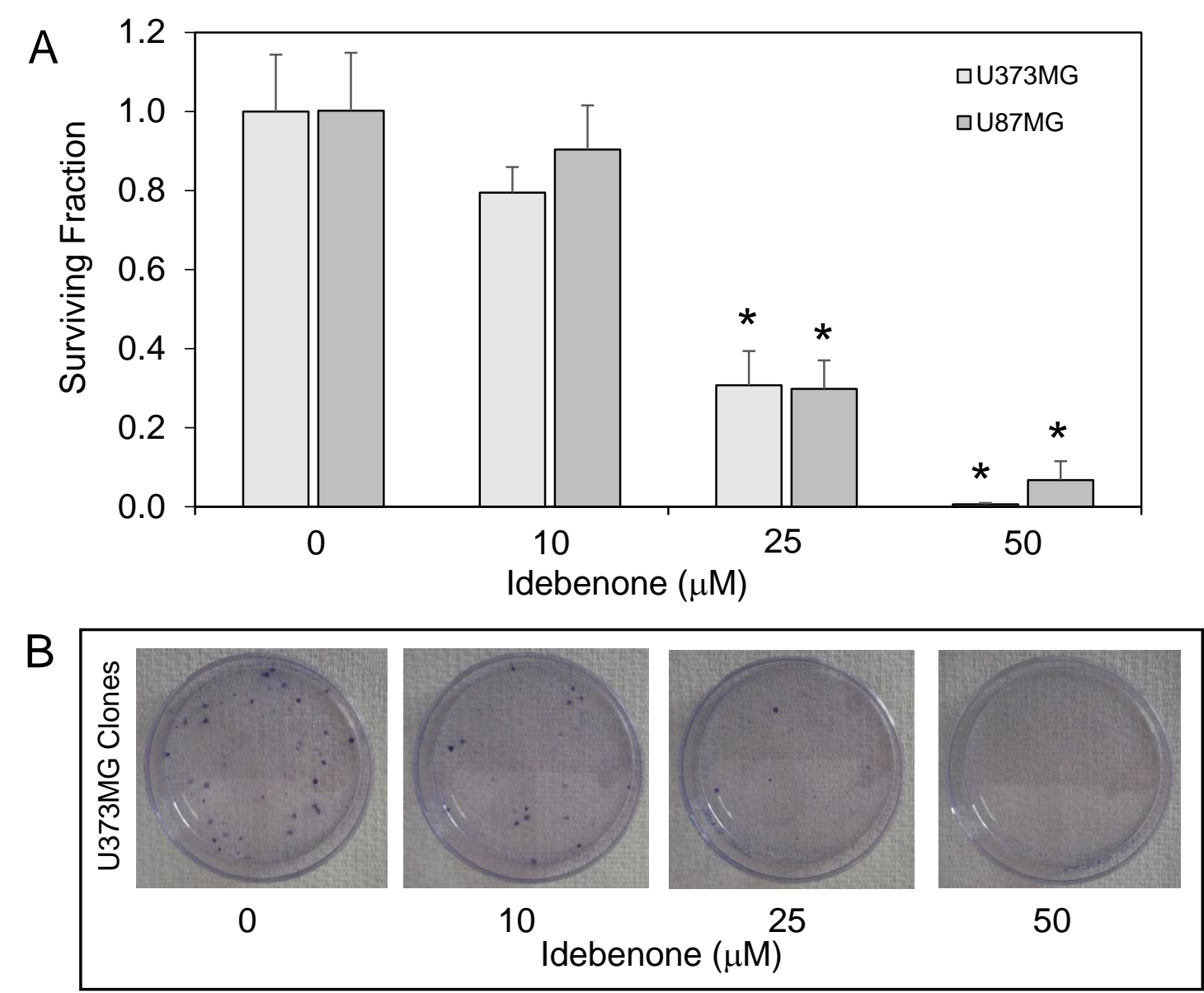

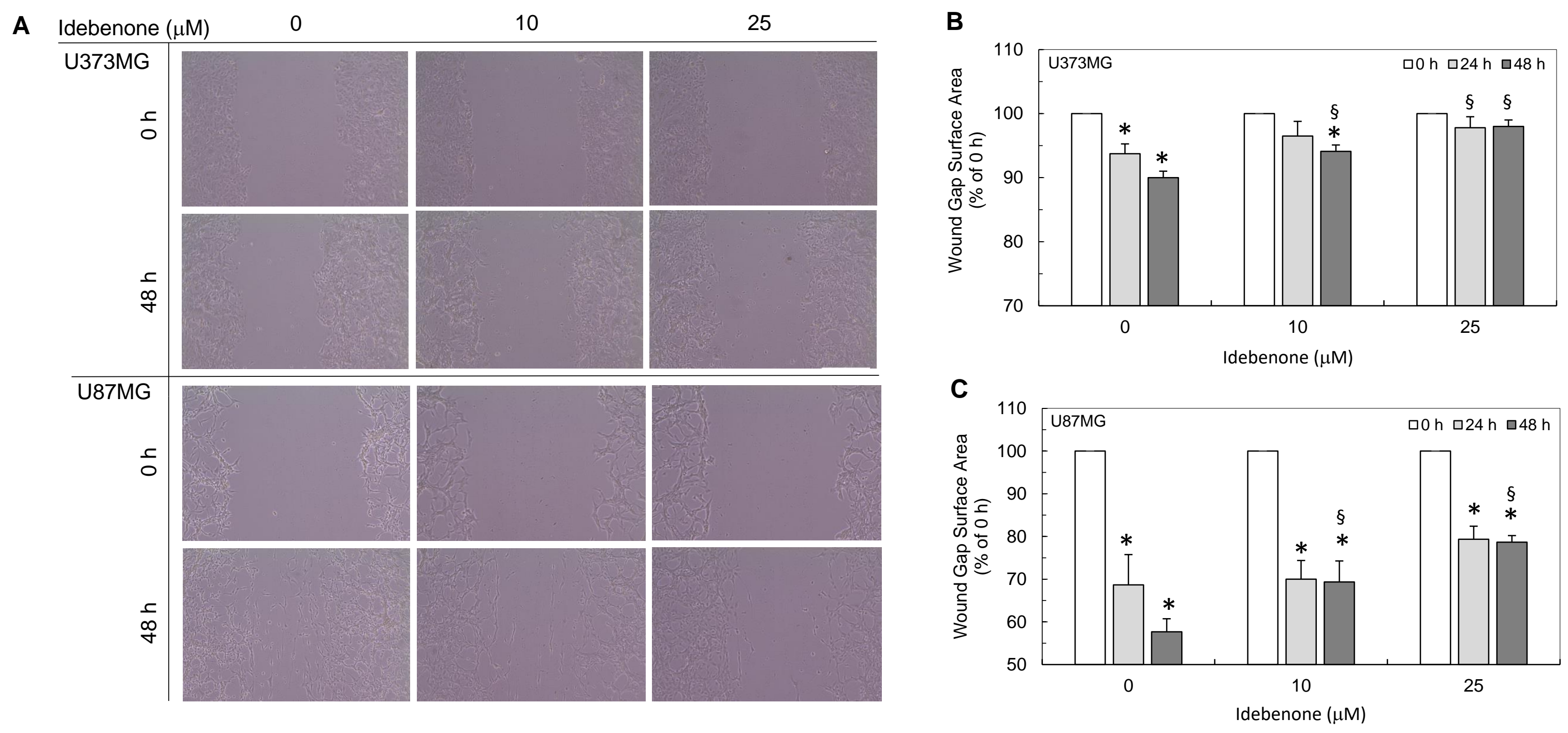

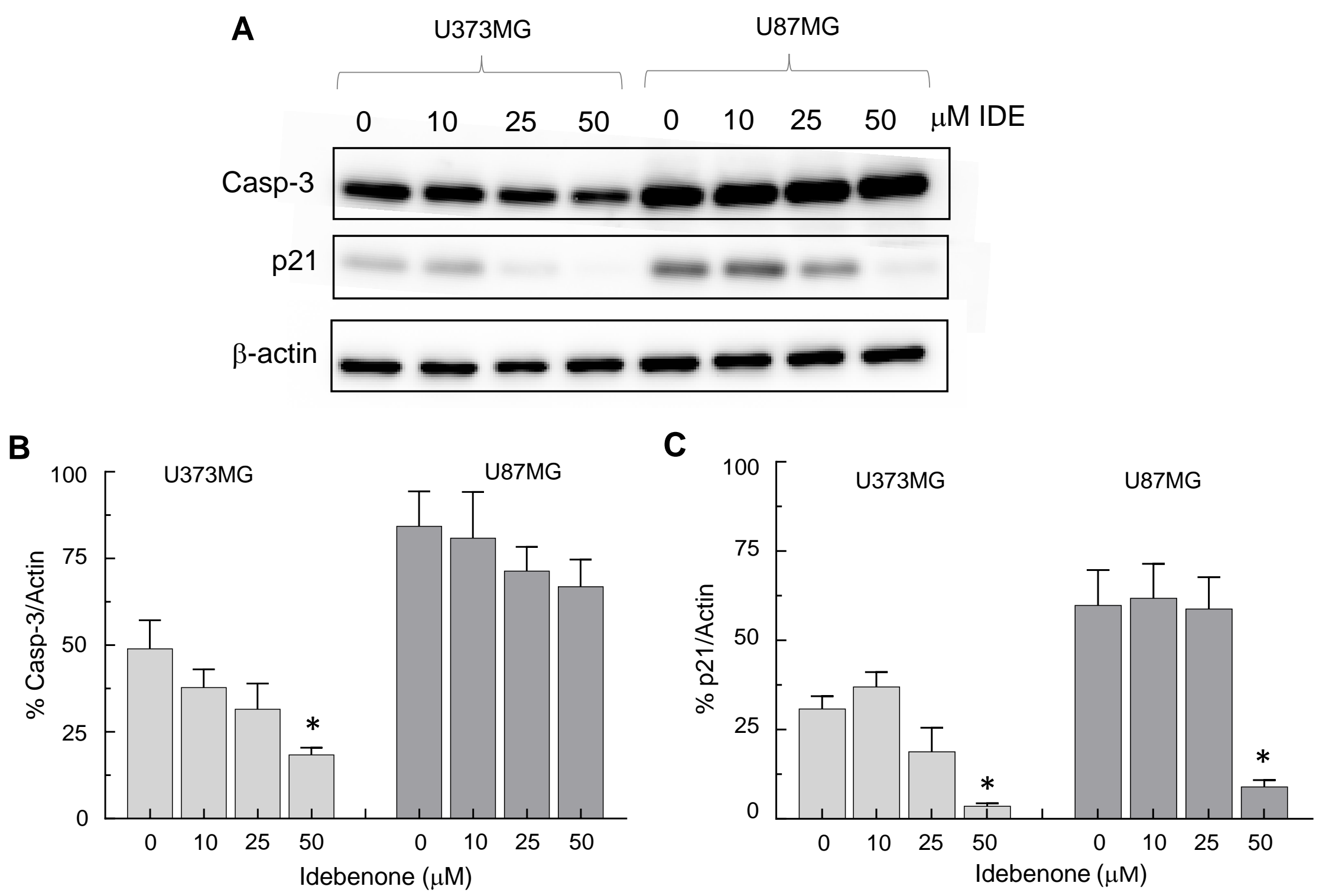

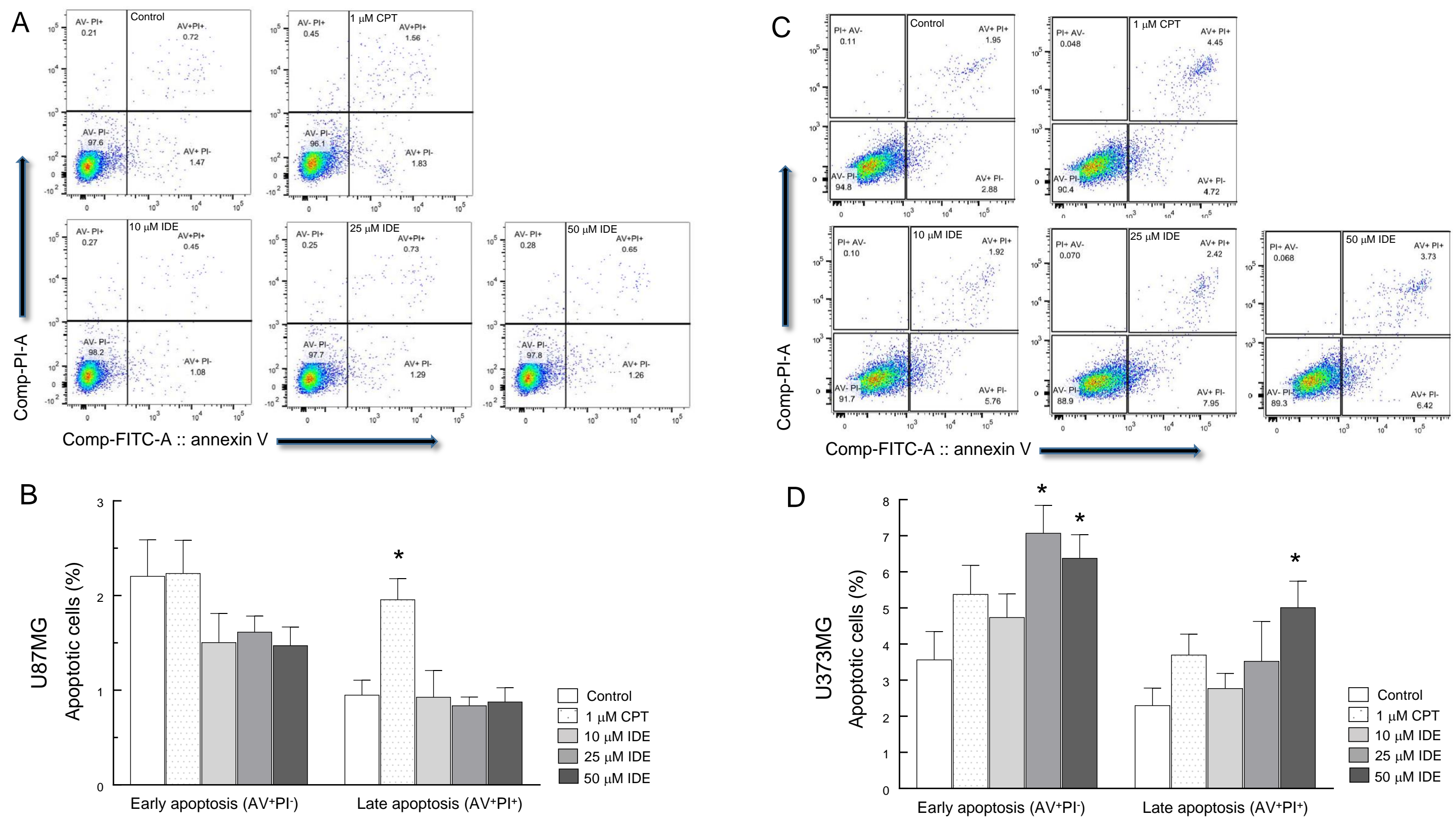

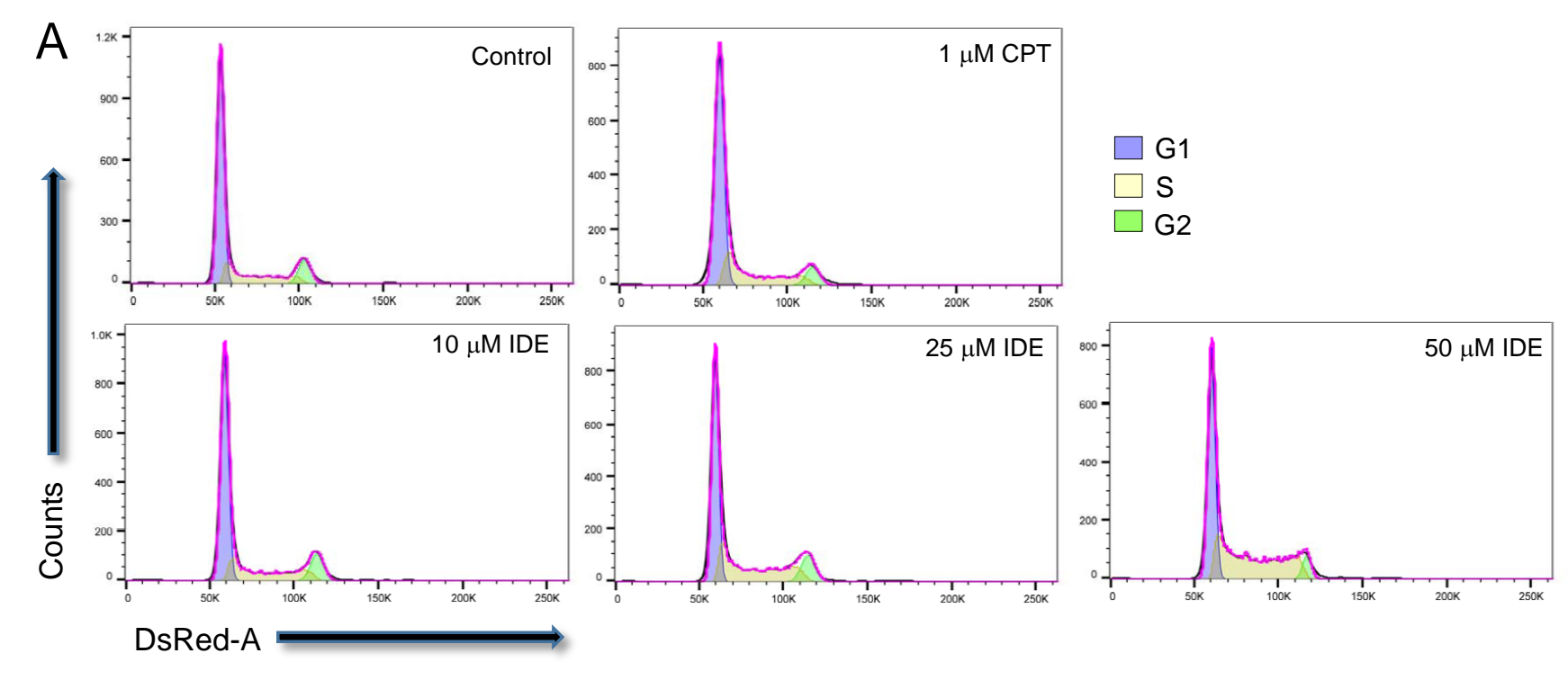

B

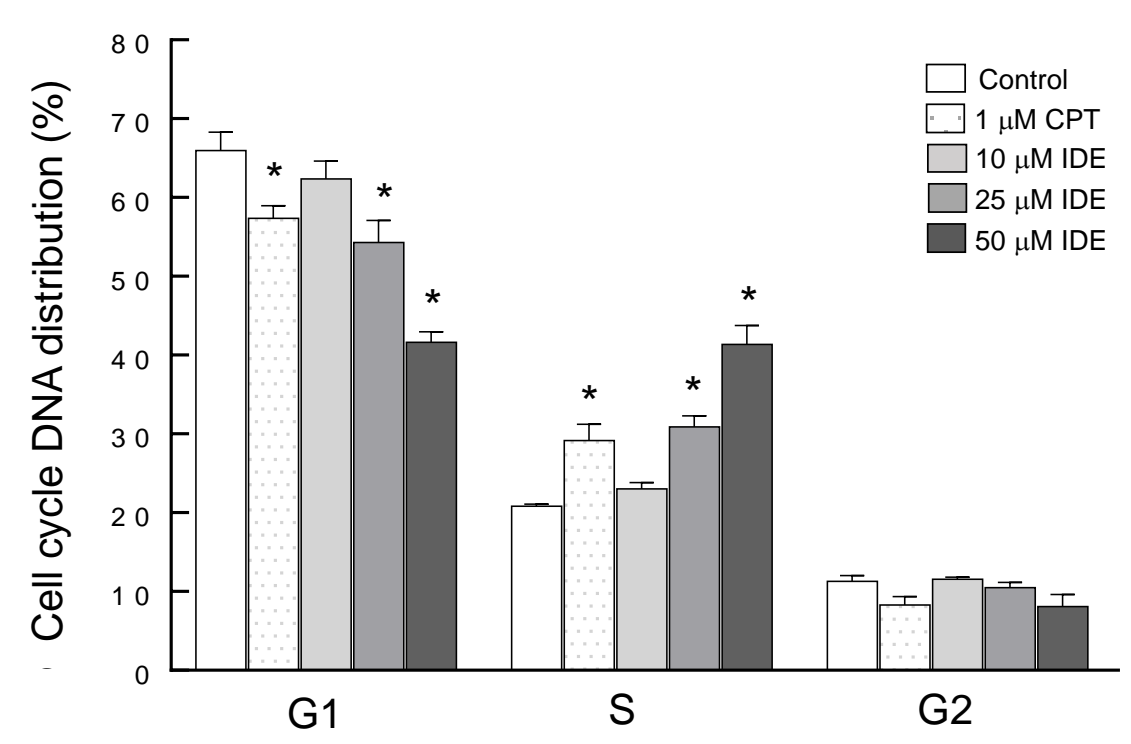

